\title{
アルミニウム双結晶における疲労き裂の発生に およぼす結晶粒界の影響*
}

\section{美馬源次郎 ${ }^{* *}$ 猪子富久治*** 安 宅 健 ${ }^{* *}$}

Genjiro Mima, Fukuji Inoko and Ken Atagi : The Effects of the Crystal Boundaries on the Initiation of Fatigue Crack in Aluminum Bicrystals. Aluminum bicrystals with longitudinal crystal boundaries with twist angles of about $22^{\circ}(0.38 \mathrm{rad})$ and $\{111\}$ planes were produced by a modified Bridgman method. They were tested by the bending fatigue testing machine under constant strain amplitude and the rate of cycles $30.4 \mathrm{~Hz}$.

It was found that fatigue cracks initiated along the crystal boundaries. The initiation of the fatigue cracks along the crystal boundaries was due to the operation of secondary slip systems whose slip planes were parallel to the crystal boundary one.

(Received May 19, 1978)

\section{I. 緒 言}

一般に繰返し変形を受けた金属の表面の粒内には，固執 すべり帯が観察される。アルミニウム怙よびアルミニウム 合金等では，この固㸉すべり带に“突き出し”呫よび “入 り込及”が形成され，これらは応力集中をともなって疲労 き裂へと発達する(1).

一方，疲労き裂は，粒界に発生することもあり，たと兄 ばアルミニウムでは Smith ${ }^{(2)}$, 銅では Kemsley ${ }^{(3)}$ ，二ッ ケルでは Laird ら ${ }^{(4)}$ ，拉よび鋼では Wood ら 䊀界き裂が巨視的に観察されている。しかしこれらは多結 晶の絽返し変形中に観察しな結果で，粒界に和ける疲労き 裂の発生について系統的に調べたものではない。

著者 ${ }^{(6)}$ は，先に，アルミニウム双結晶を用いて，粒界 が疲労き裂の発生におよぽす影響を調べた結果，両成分結 晶の主すべり采間の応力伝達係数， $N_{i j}$ 值が小さく，さら に両成分結晶または一方の成分結晶心就计る主すべり系の 粒界面に平行な転位が刃状成分よりらせん成分をより多く 子つ場合には，粒内の粒界影響部において主疲労き裂が発 生したことを報告した。これらの結果は主すべり系のらせ ん転位が粒界面に平行になるように力位制御した双結晶を 用いると粒界が疲労き裂の発生におよぼす影響が大きいこ とを示唆している。そこで双結晶の兩成分結晶に批ける主 すべり系の粒界面に平行な転位が純ら好ん転位をもつ双結

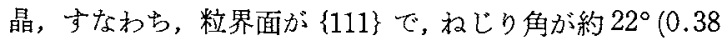
rad)の极じり粒界をもつ双結晶 (Fig.1) (7)(8)を用いて疲労 試験を行なった。 その結果, 粒界に沿ら披学き裂が発生し たので，その発生の原因を主として粒界近傍の変形機構な どから検討したものである。

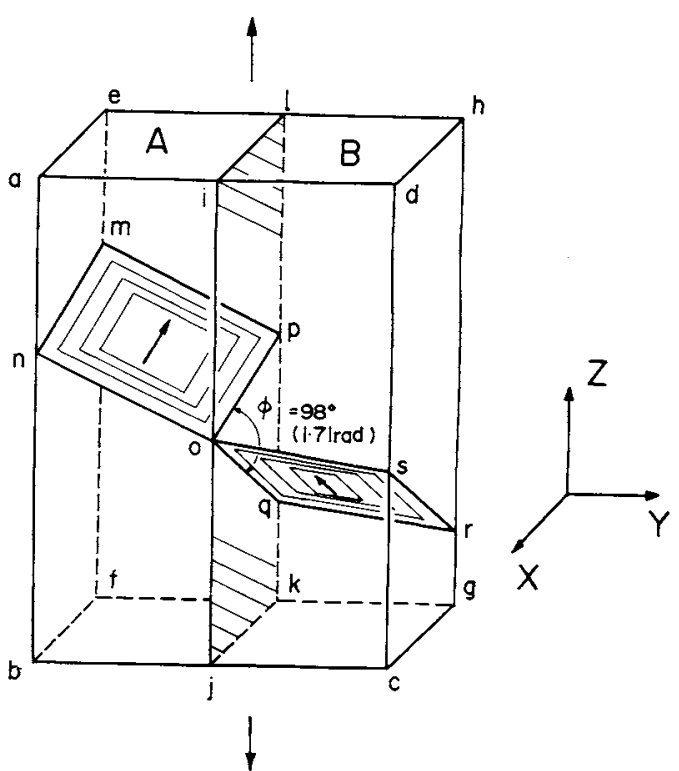

Fig.1 Schematic drawing of a bicrystal (Type 3) with a $22^{\circ}(0.38 \mathrm{rad})$ twist crystal boundary $i-j-k-1$ whose plane is $\{111\}$. The surface $a-b-c-d$ is called the front surface and the $\mathrm{e}-\mathrm{f}-\mathrm{g}-\mathrm{h}$ the back one. The planes $\mathrm{m}-\mathrm{n}-\mathrm{0}-\mathrm{p}$ and $o-q-r-s$ are primary slip planes in two component crystals $A$ and $B$, respectively. Both slip vectors intersect mutually at $98^{\circ}(1.71 \mathrm{rad})$ on the crystal boundary plane.

\section{II. 実験方 法}

純度 99.99 wt％のアルミニウム・インゴットを錢造お よび切削して得られた $4 \times 50 \times 400 \mathrm{~mm}$ のアルミニウム板 から修正ブリッジマン法によって, Type 1〜4の4 種類の

**阿南工業高等専門学校 (Anan Technical College, Anan)

**** 德島大学工業短期大学部 (Technical College, The University of Tokushima, Tokushima)

* 1977 年 4 月日本金属学会東京大会に一部発表 
粒界面が \{111\}で，水じり角が䄪 $22^{\circ}$ (0.38 rad)のアルミ こウム双結晶を作製した。これらの各 TypeのZ軸方向の 方位をFig.2に示す。図で，たと党ば，1AはType 1 の成分結晶 $\mathrm{A} の Z$ 軸方向の方位を示し，Pはく $\mathrm{P} 111>$ およ びDはく110〉を示す，求める双結晶の方位と実験によっ

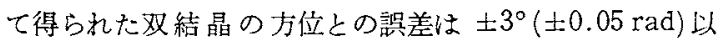
内であった。得られた双結晶素板に，メチルアルコールを十 分に与えながら Fig.3 に示す形状寸法 (応力集中係数 ${ }^{(9)}$, $\alpha=1.09$ ) の応力軸方向に粒界をるつ双結晶疲学試験 $j_{1}^{1}$ を切り出し，王水で化学研摩して加工層を十分に除去した 後, 軽くェメリ一紙で研摩し，300 C で $3 \mathrm{~h}$ 焼鈍した後， 電解研摩して疲労試験に供した。

各 Type の双結晶を2 個以上製作し，それらを試作した ンェンク式曲げ疲労試験 機 ${ }^{(6)}$ を用いて, 繰返し速度 30.4 $\mathrm{Hz}$ および試験片の表面の最大ひずみ約 $0.2 \%$ の定ひずみ 両振り曲げ疲労試験を行なった，このひずみは，双結晶に 和ける両成分結晶の主すべり系が優先的に活動し, 2 次す ベり系の活動の影響が少ないような変形状態を得るために

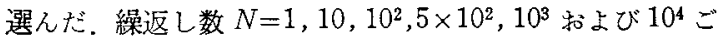
とに，それ以後は適当な繰返し数に和いて試験機を停止

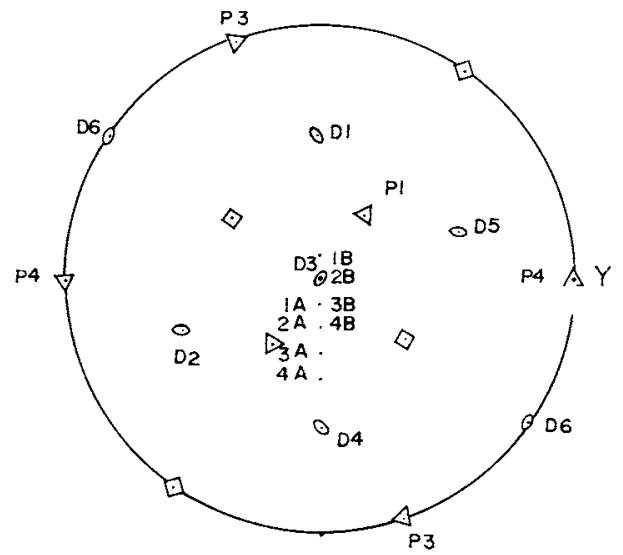

Fig.2 Tensile axes of two component crystals $A$ and $B$ in four types of bicrystal.

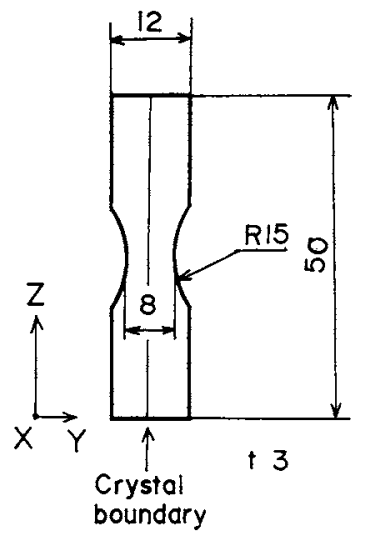

Fig.3 Dimension of fatigue specimen.
し, 疲労变形中のすべり変形の様子および疲労き裂の伝ぱ を光学䫓碝鏡で観察した。

\section{III. 実 験 結 果}

Type 3 および4の双結晶の和子て面(Fig.1)に粒界に 沼亏疲労き裂が発生した。 Type 3 の双結晶に和忛る両成 分結晶の方位のステレオ投影因をFig.4 に示す。ここで， たとえば，P 3 D $3 \mathrm{~A}$ は成分結晶 Aのすべり面 P 3 および 寸ベり方向 D $\overline{3}$ のすべり系を示す. D 3 とD $\overline{3}$ とは互いに 逆方向のすべり方向を示す．実線は主すべり系，P 3 D 3-

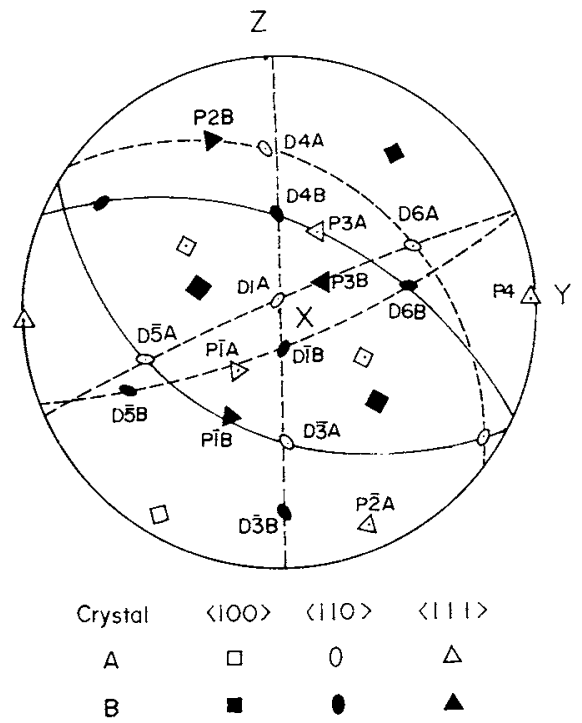

Fig.4 Stereographic projections of two component crystals $A$ and $B$ in the Type 3 bicrystal.

(- Trace of primary slip system,

$\mathrm{D} \overline{3} \mathrm{~A} \dagger$ および P ID 4-D $4 \mathrm{~B}$ のすべり軌跡を，破楾は2

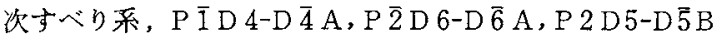
およびP 4 D 3-D 3 B のすべり軌跡を示す. Photo.1 Type 3 の双結晶の繰返し数の增加にともな5执て面抹 上びうら面の粒界近傍のすべり带の変化をほぼ同一視野で 示す。繰返乙数 $N=1$ では，おもて面において，主すべり 系, P 3 D 3-D $\overline{3}$ A および P 1 D 4-D 4 B の活動心加光て, わずかに2 次すべり系, P $\overline{1} \mathrm{D} 4-\mathrm{D} \overline{4} \mathrm{~A}$ の活動が観察され たＰ３Ｄ3-D 3 A のすべり系のらせん転位は，P1D4D 4 B のすべり系のらせん転位で粒界に形成される転位壁 に质力を受ける(Table 1) (7)(10)ために，P 3 D 3-D $\overline{3}$ A の すべり带は粒界に達していなかった。一方，与ら面におい ては，主すべり系，P 3 D 3-D $\overline{3}$ A および P 1 D 4-D $\overline{4}$ B に 加古て，おるて面と異なる2次すべり系，P 2 D 6-D $\overline{6}$ A および P 2 D 5-D 5 B の活動が粒界近傍で観察された、さ らに繰返し数 $N=10^{2}$ においては, おすて面に, 两成分結

† P 3 D 3-D 3 A は成分結晶Aのすべり面が P3で,す ベり方向が P 3 とその逆の D 3 のすべり系を示す. 


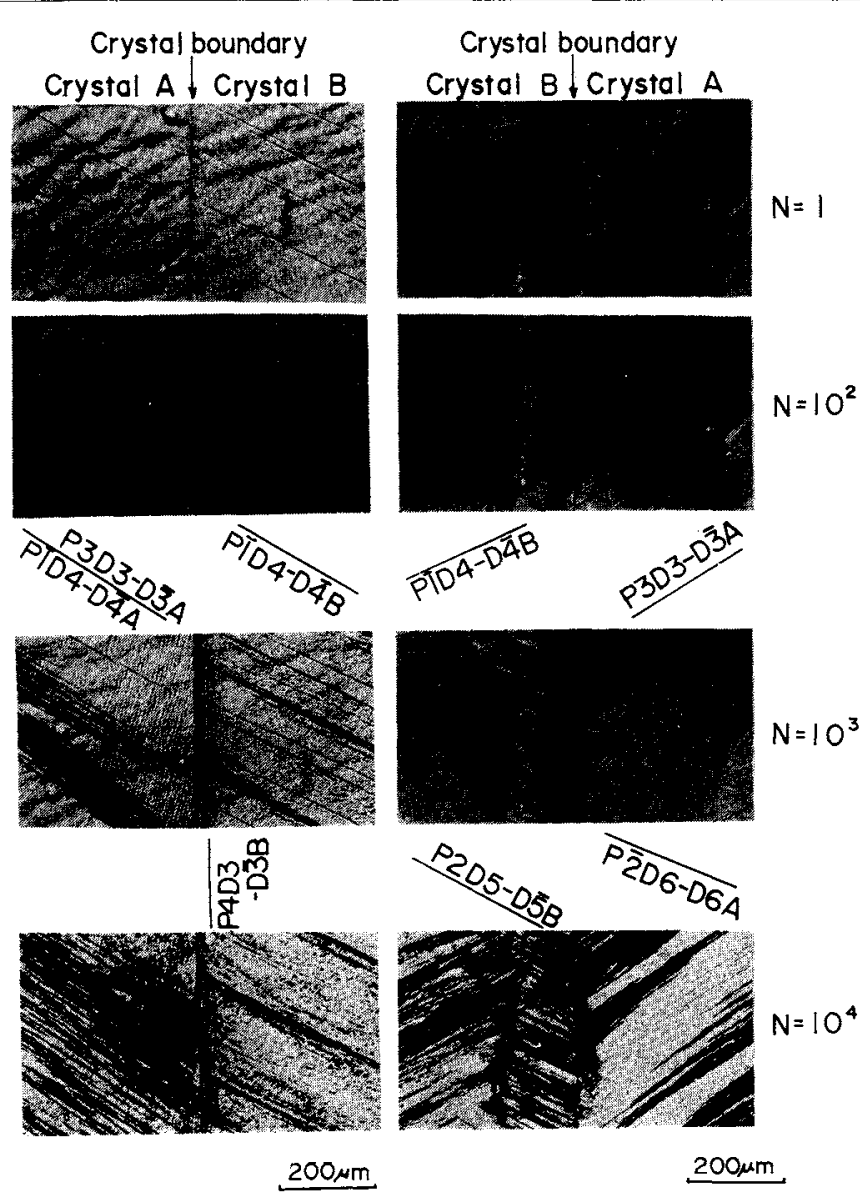

(a) The front surface (b) The back surface

Photo.1 The variation of slip bands near the crystal boundary in the Type 3 bicrystal with the increase of number of cycles.
面に光学顕 钽鏡(100 倍)によって観察され た粒界に沼与微小疲労き裂の一例を示す。

Photo.3に，繰返し数 $N=1.5 \times 10^{4}$ に和け る成長した粒界き裂を示す。き裂の開口は粒 界に沿って約 $1 \mathrm{~mm} こ ゙ と に$ 絞られ，その中央 部は口を開いている。このき裂は粒界に沼っ て点在して創成されたき裂が連結し成長した ものである。これらの試験片に発生する疲労 き裂としては，粒界份㳂うき裂が最も早く， それらから両成分結晶内へき裂が伝ぱした (Photo.4)が，試験片を最終破壊に導いたき 裂は，Photo.5に示すように，粒界き裂の発 生後，成分結晶Aのヘリ部に発生したき裂で あった。それが主すべり帯に沿って階段的に 位ぱし，粒界き裂と連結した後，成分結晶B 内を通って, 繰返し数 $N=1.8 \times 10^{5}$ で試験片 を最終破懐させた。この試駼片の横断面をバ フ研摩しェッチピットを形成させた写真を Photo.6に示す. Photo.6(b)は Photo.6(a) の実線で因まれた部分の抬大写真である、粒 界を介してエッチピットの形状が異なってい るのが涩められ，光学顕徽鏡(400倍) みるがりでは，扣もて面の粒界にき裂が発 生しそそれ沼って伝ぱしたと判断される。 破断後の粒界に沿ったき裂深さは，試験片 の最㹨部に近い部分で約 $1 \mathrm{~mm}$ であった。 Type 4 の場合も, Type 3 と類似した変形 様相を呈し，おをて面では，2次すべり系と して粒界面に平行なすべり面をるつすべり

Table 1 The interaction force between the screw dislocation wall and approaching screw dislocations in four types of bicrystals (in the case of tensile stress).

\begin{tabular}{|c|c|c|c|c|}
\hline Type & Screw dislocation wall & Approaching screw dislocation & $\phi^{\circ}(\mathrm{rad})$ & Direction of force \\
\hline $\begin{array}{c}1 \\
{[2]}\end{array}$ & $\begin{array}{l}P \overline{1} D 4 A \\
\text { left-handed } \\
P \overline{1} D 4 A \\
\text { left-handed }\end{array}$ & $\begin{array}{l}P 2 D \overline{1} \\
\text { left-handed } \\
\text { PID } 4 B \\
\text { right-handed }\end{array}$ & 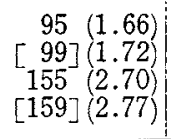 & $\begin{array}{l}\text { attractive } \\
\text { attractive }\end{array}$ \\
\hline $\begin{array}{c}3 \\
{[4]}\end{array}$ & $\begin{array}{l}P 1 D 4 B \\
\text { right-handed } \\
\text { P ID } 4 \mathrm{~B} \\
\text { right-handed } \\
\text { P } 3 \text { D } \overline{3} \text { A } \\
\text {-(right-handed) }\end{array}$ & $\begin{array}{l}\text { P } 3 D \overline{3} A \\
\text { - (right-handed) } \\
\text { P } 2 \mathrm{D} 6 \mathrm{~A} \\
\text { right-handed } \\
\text { P } 2 \mathrm{D} \overline{\mathrm{B}} \mathrm{B} \\
\text { - (right-handed) }\end{array}$ & $\begin{array}{l}98(1.71) \\
{\left[\begin{array}{l}98] \\
54\end{array}(1.71)\right.} \\
{\left[\begin{array}{l}53 \\
53\end{array}(0.94)\right.} \\
54(0.94) \\
{\left[\begin{array}{l}53](0.92)\end{array}\right.}\end{array}$ & $\begin{array}{l}\text { repulsive } \\
\text { attractive } \\
\text { attractive }\end{array}$ \\
\hline
\end{tabular}

晶の主すべり系に加えて，粒界面に平行なすべり面をもつ

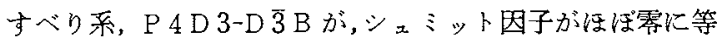

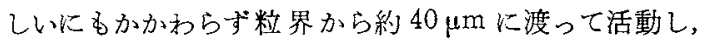
粒界汇近つくに従ってしだい激しく活動しているのが観 察された。繰返し数を増加すると，扣もて面抏よびらら面と もに既に活動しているすべり系がさらに激しく活動した。

Photo. 2 には，繰返し数 $N=1.2 \times 10^{4}$ に批いて，扣子て
采, P 4 D 3-D $\overline{3}$ B が活動し, 繰返し数 $N=10^{5}$ に和いて粒 界に沿万疲労き裂が観察され，万ら面では，それは認から れなかった。

一方, Type 1和よび2の奴結晶では, 粒界に沿ら疲労

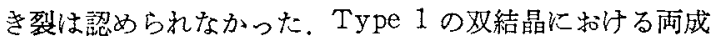
分結晶の方位のステレオ投影図を Fig.5に示す．実線は 主すべり系, P ID4-D 4 A なよび P 2D 1-D IB のすべり 


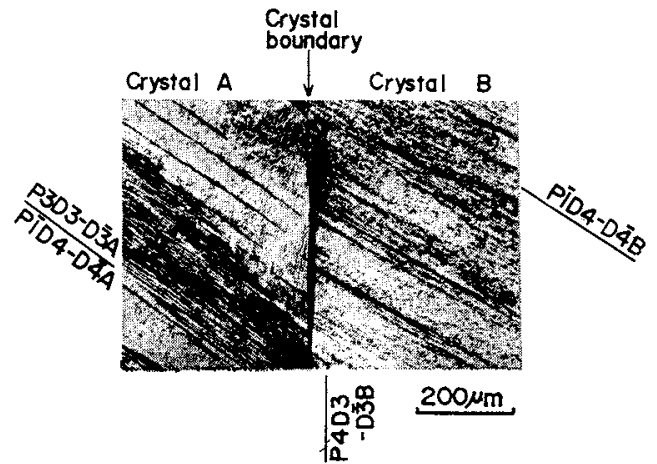

Photo.2 A fatigue microcrack initiated along the crystal boundary at $N=1.2 \times 10^{4}$ in the Type 3 bicrystal.

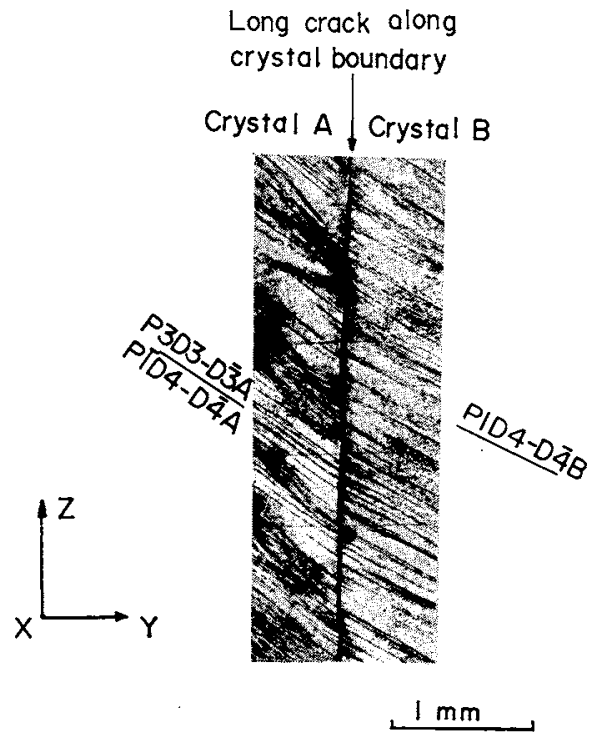

Photo.3 A long fatigue crack grown from the connection of some short cracks along the crystal boundary at $N=1.5 \times 10^{4}$ in the Type 3 bicrystal.

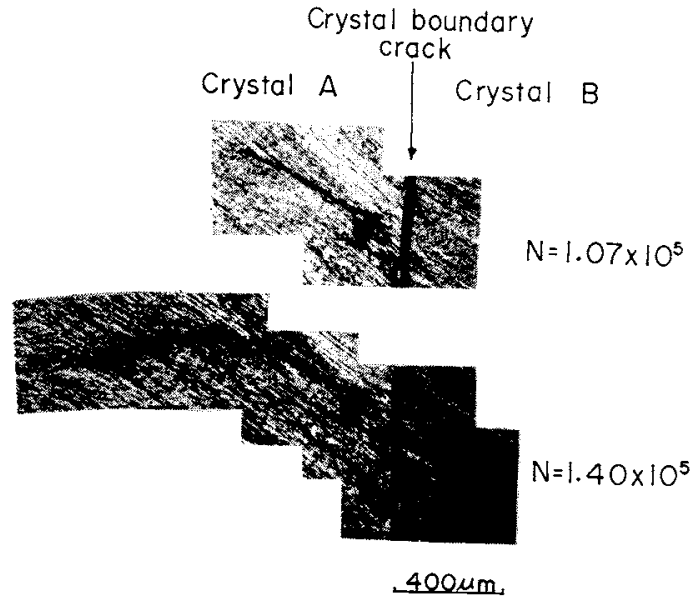

Photo.4 A ftaigue crack propagated into two component crystals from the crystal boundary crack in the Type 3 bicrystal.
軌跡を示卞.Photo.7 に, Type 1 のお百面およびうら 面の繰返し数 $N=500$ に和ける粒界近傍のすべり帯のよう すを示す。括もて面执よ゙゙らら面ともに，主すべり系， PID 4-D 4 A 和よび P 2 D 1-D I B の活動が観察された が，前述の Type 3 および4のおるて面に観察さ能た粒界 面に平行なすべり面をもつすべり系の活動は観察されなか

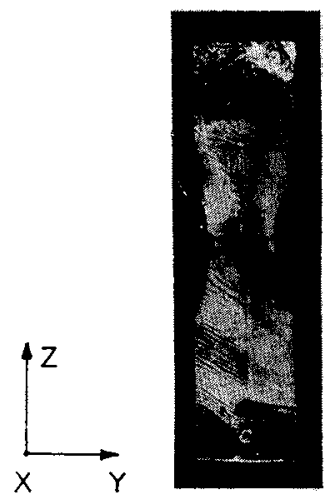

Photo.5 Microphotograph of the specimen fractured at $N=1.8 \times 10^{5}$ in the Type 3 bicrystal. The main crack nucleated at the left corner and propagated along the primary slip bands. Then, it connected the crystal boundary crack which had already initiated, and propagated into the right crystal.

$\begin{array}{cccc}\text { Crystal } & \text { Crystal } & \text { Crystal } & \text { Crystal } \\ \text { A } & \text { B } & \text { A } & \text { B }\end{array}$

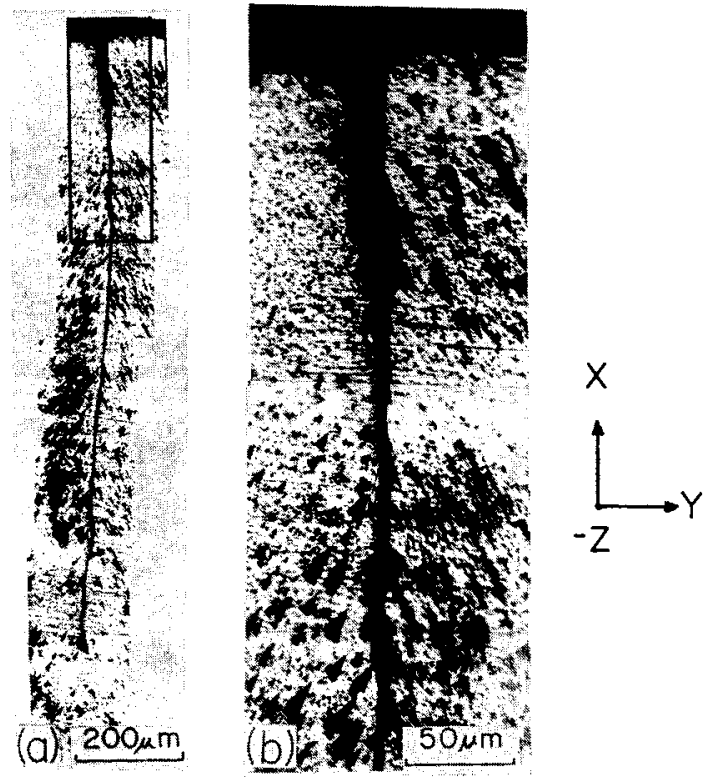

Photo.6 Photographs of etch-pits on a cross section of the Type 3 bicrystal. It is shown that the fatigue crack propagated along the crystal boundary microscopically. 


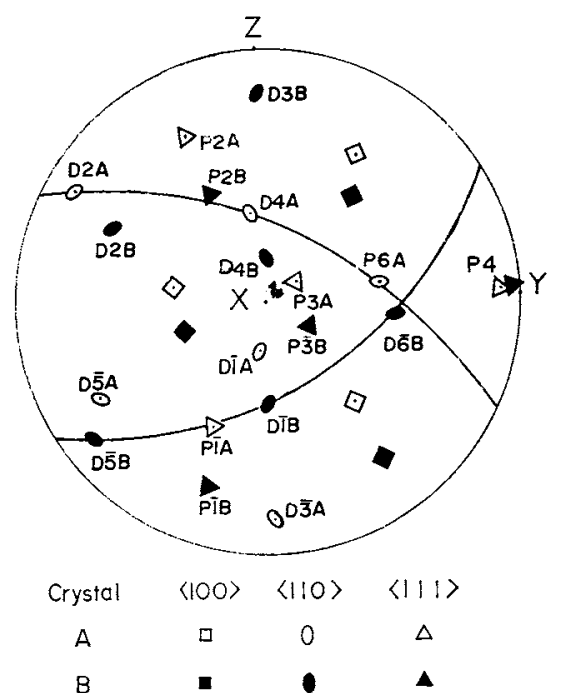

Fig.5 Stereographic projections of two component crystals $A$ and $B$ in the Type 1 bicrystal. - Trace of primary slip system,
- Trace of secondary one)

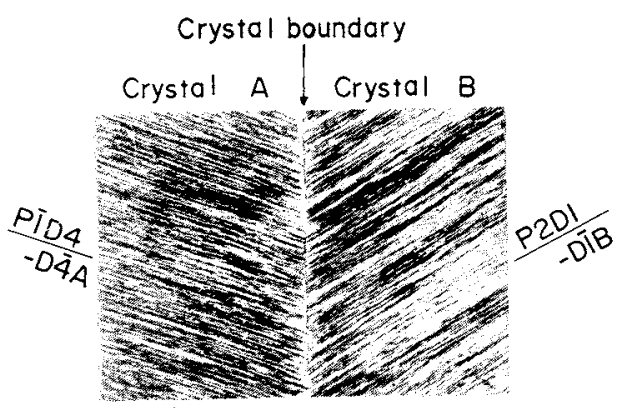

(a)

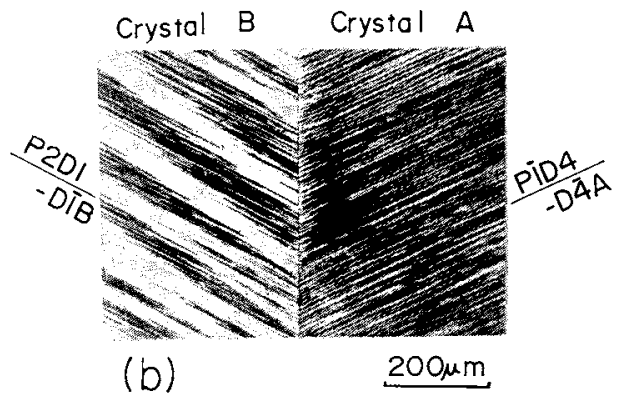

Photo.7 Slip bands observed at $N=500$ near the crystal boundary in the Type 1 bicrystal.
(a) The front surface
(b) The back surface

った．主すべり系，P更D 4-D $\overline{4}$ A のらせん転位は，主与 ベり系，P2D1-D1Bのらせん転位で粒界に形成される 転位壁と互いに引力を和よぼし合5(Table 1)ために，こ れらのすべり带は粒界に達しているのが観案された。さら に繰返し数を堌加するとここ礼ら既存のすべり带はさらに 激しく発㾕した。しかし粒界に沼ら疲労き裂は認められず，
試験片のへリ部に発生したき裂が成長し，試験片を最終破 壊にいたらしめた。 Type 2 の場合も、Type 1 とほほ類 似した疲学変形㥞相を呈し，粒界に沿与疲学き裂の発生は 認められなかった。

\section{IV. 考察}

疲労き裂が，Type 3 和よび4の双結晶の和もて面の粒 界に沼って生じ，それらのらら面执よび Type 1 おょび 2 の雨面には生じなかった。また,この粒界に沿ら疲労き裂 の発生には，粒界面に平行なすべり面をるつすべり系， P 4 D 3-D 3B の粒界近傍での活動が伴っていた。このす ベり系の活動が：シェミット因子が零にもかかわらず生じ たことは，粓界近傍に局所せ九断応力，士 $\tau_{y z}$ が生じたこ とを示している。

一般に，双結晶(Fig.1)の粒界で，成分結晶A が弾性ひずみの compatibilityを維持するためには，粒

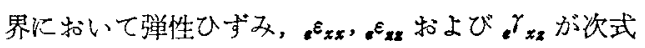

$$
\stackrel{\mathrm{A}}{\mathrm{A}}={ }_{e} \varepsilon_{x x}^{\mathrm{B}},{ }_{e} \varepsilon_{z x}^{\mathrm{A}}={ }_{e} \varepsilon_{z z},{ }_{e} \gamma_{x z}^{\mathrm{A}}={ }_{e} \gamma_{x z}^{\mathrm{B}}
$$

を满足しなければならない。

弾性ひず双に incompatibilityをるつ双結晶が粒界で 式(1)を満足するよらに弾性変形するためには，粒界で弾 性ひずみの compatibilityを維持するに必要な大きさの 局所応力が発生しなければならない。ここで，1軸変形を 例婂，両成分結晶の弾性ひずみ成分， $\gamma_{x z}$ の incompatibilityによって粒界近傍に生ずる局所せん断応力，士 $\pm \tau_{y_{x}}$ がいかにして発生するかを Fig.6 (11) に示す。これらの局 所过九断応力，士 $\tau_{y z}$ は双結晶の粒界面で最も大きく，粒 界面より離れるに従って，また双結晶表面から内部にはい るに従って減少する，双結晶が破線で示すよらに弾性変形

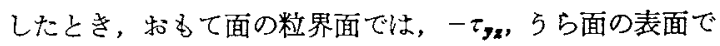
は, $+\tau_{y x}$ の世ん断応力が発生する。これらのせん断応力,

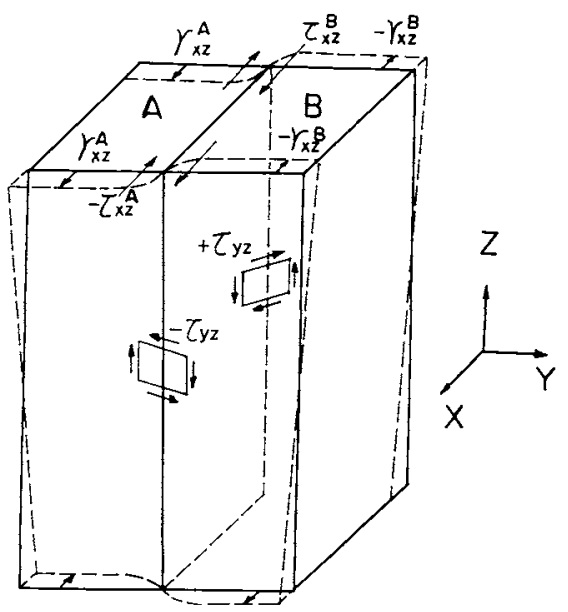

Fig.6 Schematic illustration showing how stresses $\pm \tau_{x z}$ and $\pm \tau_{y x}$ arise from the incompatibility of elastic strain $\gamma_{x z}$. 


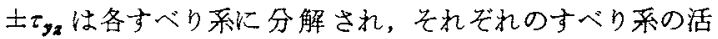
動を促進させたり，抑制させたりする。士 系に分解寸る方位因子， $N_{i j}\left( \pm \tau_{y_{z}}\right)$ 值は，店力伝详係数， $N_{i j}$ 值を求める場合と同じ方法で求めることができる。こ こで，正の $N_{i j}\left( \pm \tau_{y_{z}}\right)$ 傗は今考えているすべり系の活動を しやすくし，一方，負の值はすべり系の活動を㧕制(11)(12) する，双結晶をZ軸方向に変形させたとき，個々の成分結 晶の弾性ひずる成分は,

$$
\begin{aligned}
& \varepsilon_{z x}=\mathrm{S}_{13} \sigma_{z z}, \varepsilon_{y y}=\mathrm{S}_{23} \sigma_{z z},{ }_{e} \varepsilon_{z z}=S_{33} \sigma_{z z} \\
& e_{x y}=\mathrm{S}_{43} \sigma_{x z}, \gamma_{z z}=\mathrm{S}_{53} \sigma_{z z}, \gamma_{y z}=S_{63} \sigma_{z z}
\end{aligned}
$$

とあらわされる。ここで, $\mathrm{S}_{i j}$ は弾性コンブライアンスを, $\sigma_{z z}$ はZ軸方向の応力を示马．本研究の各 Type の双結晶 の場合，䊀界面が $\{11\}$ で，両成分結晶のZ軸方向の方位

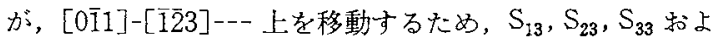
び $S_{53}$ は各Type の双結晶の成分結晶に拈いて一定の值 をとり，この種の双結晶の粒界近傍では，兩成分結晶の弾 性変形範囲での弾性ひずみの incompatibility から生じ る局所応力は発生しないものとみなされる。

事実, 粒界面に平行なすべり面学毛つすべり系の活動は Photo.1にむ示されているように，繰返しの増加による主 すべり系の活動の増加に従って増加しており，主すべり系

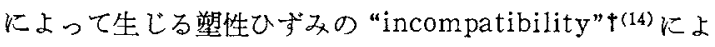
るものと孙される。ここで, P4D3-D ̄ B と隣接結晶 の主すべり系，P 3 D 3-D 3 A との応力伝達俰数， $N_{i j}$ 値 は0.29で小さく，またPĪD 4-D 4 A のそれも0.17 と小 さい.そのため P 4 D 3-D 3 B の活動は応力伝達係数, $N_{i j}$ 値から説明することができない。

Livingston 执よびChalmers(13)の定義した粒界に竹け る両成分結晶の塑性ひずみの compatibilityを主すべり 系, P 3D $\overline{3}$ \& P ID4BKついて, Table 2 よみて

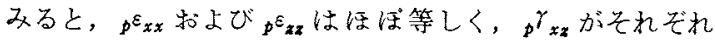
0.16 と 0.03 でやや差が大きい，乙かしながら，この程度 の差は粒界に沿ら疲学き裂が発生しなかった Type 1 およ び 2 の双結晶の主すべり系間に和いてる存在している(7).

したがって，この塑性ひずみの incompatibility からも,

Table 2 Plastic strain components of main slip systems in the Type 3 bicrystal

\begin{tabular}{|c|c|c|c|}
\hline Slip system & $p \varepsilon_{x x}$ & $\varepsilon_{t x}$ & ${ }_{p}^{\gamma} \gamma_{x z}$ \\
\hline $\begin{array}{l}\mathrm{P} 3 \mathrm{D} 3 \mathrm{~A} \\
\mathrm{P} 2 \mathrm{D} 6 \mathrm{~A} \\
\mathrm{P} 1 \mathrm{D} 4 \mathrm{~A} \\
\mathrm{P} 2 \mathrm{D} 1 \mathrm{~A} \\
\mathrm{P} 1 \mathrm{D} 4 \mathrm{~B} \\
\mathrm{P} 2 \mathrm{D} 5 \mathrm{~B} \\
\mathrm{P} 2 \mathrm{D} 1 \mathrm{~B} \\
\mathrm{P} 4 \mathrm{D} 3 \mathrm{~B}\end{array}$ & $\begin{array}{l}-0.46 \\
-0.05 \\
-0.40 \\
-0.07 \\
-0.48 \\
-0.12 \\
-0.28 \\
-0.01\end{array}$ & $\begin{array}{l}0.43 \\
0.32 \\
0.39 \\
0.09 \\
0.47 \\
0.38 \\
0.25 \\
0.01\end{array}$ & $\begin{array}{r}0.16 \\
0.22 \\
-0.34 \\
0.47 \\
0.03 \\
0.14 \\
-0.40 \\
0.01\end{array}$ \\
\hline
\end{tabular}
(in the case of tensile stress).

$\dagger$ Livingston および Chalmers ${ }^{(13)}$ によって定義され た塑性ひずみの compatibilityに，粒界を介した 両成分結晶の集団的な転位の相互作用を考虑したも $\sigma^{(7)}$.
先の P 4D 3-D 3 B が活動したとは考えられない。

前述したよ5に, Type 3 および4の双結晶は成分結晶 Bの主すべり系，P五 4-D $\overline{4}$ B の活動により粒界に生じ たらせん転位壁(精界面に平行に粒内に生じている可能 性もある)が隣接結晶の主すべり系, P 3 D 3-D 3 A K長範 国な斥力を和よぼしその活動を抑制するために，P３Ｄ３D $\overline{3} \mathrm{~A}$ は粒界まで達することがでさない，その後粒界に達 しているすべり带は, 引力を受けるPID 4-D 4 A のbせ ん転位によるすべり帯とみなされる，P1D4Aのすべり 系は $\gamma_{x z}$ が 0.34 と大きく, P I D 4 B の 0.02 と比べると

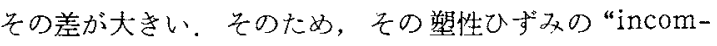
patibility”を解消するよらに，粒界近傍に局所せ九断応 力， $\tau_{y_{z}}$ が発生したものとみなされる。

ここで, 各 Type の效結晶における引张変形持のお子

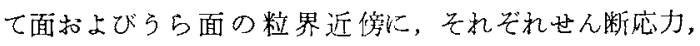
一神z の代表的なすべり系比分解した方位因子， $N_{i j}\left( \pm \tau_{y_{z}}\right)$ 值を Table 3 に示す。括むて面では，Type 1 扎よび 2 の P 4 D 3 A 和上びP 4 D 3 B ならびに Type 3 和よび 4 の P 4 D $\overline{3}$ B の方位因子, $N_{i j}\left(-\tau_{y_{z}}\right)$ 值が 0.95 以上の非常に 高い値をもっていることがわかる、したがって，各 Type

Table 3 Orientation factor $N_{i j}$ for resolved shear stress $\pm \tau_{y z}$ onto main slip systems in four types of bicrystals (in

\begin{tabular}{|c|c|c|c|c|}
\hline Type & $\begin{array}{l}\text { Slip } \\
\text { system }\end{array}$ & $\begin{array}{l}N_{i j}\left(-\tau_{y z}\right) \\
\text { (the front } \\
\text { surface) }\end{array}$ & $\begin{array}{r}N_{i j}\left(+\tau_{y_{z}}\right) \\
\text { (the back } \\
\text { surface) }\end{array}$ & $\begin{array}{l}\text { Schmid } \\
\text { factor }\end{array}$ \\
\hline \multirow{2}{*}{1} & $\begin{array}{l}\mathrm{P} \overline{1} \mathrm{D} 4 \mathrm{~A} \\
\mathrm{P} 2 \mathrm{D} \overline{\mathrm{A}} \\
\mathrm{P} 4 \mathrm{D} \overline{\mathrm{A}}\end{array}$ & $\begin{array}{r}-0.06 \\
-0.55 \\
0.99\end{array}$ & $\begin{array}{r}0.06 \\
0.55 \\
-0.99\end{array}$ & $\begin{array}{l}0.47 \\
0.39 \\
0.02\end{array}$ \\
\hline & $\begin{array}{lllll}\mathrm{P} & 2 & \mathrm{D} & 1 & \mathrm{~B} \\
\mathrm{P} & 2 & \mathrm{D} & 6 & \mathrm{~B} \\
\mathrm{P} & 4 & \mathrm{D} & 3 & \mathrm{~B}\end{array}$ & $\begin{array}{r}0.13 \\
-0.37 \\
0.96\end{array}$ & $\begin{array}{r}-0.13 \\
0.37 \\
-0.96\end{array}$ & $\begin{array}{l}0.50 \\
0.37 \\
0.00\end{array}$ \\
\hline \multirow{2}{*}{2} & $\begin{array}{lllll}\mathrm{P} & \overline{1} & \mathrm{D} & 4 & \mathrm{~A} \\
\mathrm{P} & 2 & \mathrm{D} & 5 & \mathrm{~A} \\
\mathrm{P} & 4 & \mathrm{D} & \overline{3} & \mathrm{~A}\end{array}$ & $\begin{array}{r}-0.21 \\
-0.60 \\
0.96\end{array}$ & $\begin{array}{r}0.21 \\
0.60 \\
-0.96\end{array}$ & $\begin{array}{l}0.47 \\
0.36 \\
0.02\end{array}$ \\
\hline & $\begin{array}{lllll}\mathrm{P} & 2 & \mathrm{D} & \overrightarrow{1} & \mathrm{~B} \\
\mathrm{P} & 2 & \mathrm{D} & \overline{5} & \mathrm{~B} \\
\mathrm{P} & 4 & \mathrm{D} & 3 & \mathrm{~B}\end{array}$ & $\begin{array}{r}0.19 \\
-0.46 \\
1.00\end{array}$ & $\begin{array}{r}-0.19 \\
0.46 \\
-1.00\end{array}$ & $\begin{array}{l}0.44 \\
0.41 \\
0.00\end{array}$ \\
\hline \multirow[t]{2}{*}{3} & $\begin{array}{l}\mathrm{P} 1 \mathrm{D} 4 \mathrm{~A} \\
\mathrm{P} 3 \mathrm{D} \overline{\mathrm{A}} \\
\mathrm{P} 2 \mathrm{D} 6 \mathrm{~A} \\
\mathrm{P} 4 \mathrm{D} \overline{\mathrm{A}}\end{array}$ & $\begin{array}{r}-0.31 \\
-0.25 \\
-0.63 \\
0.82\end{array}$ & $\begin{array}{r}0.31 \\
0.25 \\
0.63 \\
-0.82\end{array}$ & $\begin{array}{l}0.35 \\
0.43 \\
0.32 \\
0.01\end{array}$ \\
\hline & $\begin{array}{lllll}\mathrm{P} & \overline{1} & \mathrm{D} & 4 & \mathrm{~B} \\
\mathrm{P} & 2 & \mathrm{D} & \overline{5} & \mathrm{~B} \\
\mathrm{P} & 4 & \mathrm{D} & 3 & \mathrm{~B}\end{array}$ & $\begin{array}{r}-0.24 \\
-0.58 \\
0.96\end{array}$ & $\begin{array}{r}0.24 \\
0.58 \\
-0.96\end{array}$ & $\begin{array}{l}0.47 \\
0.38 \\
0.01\end{array}$ \\
\hline \multirow[t]{2}{*}{4} & $\begin{array}{lllll}\mathrm{P} & \mathrm{1} & \mathrm{D} & 4 & \mathrm{~A} \\
\mathrm{P} & 3 & \mathrm{D} & \overline{3} & \mathrm{~A} \\
\mathrm{P} & 2 & \mathrm{D} & 6 & \mathrm{~A} \\
\mathrm{P} & 4 & \mathrm{D} & \overline{3} & \mathrm{~A}\end{array}$ & $\begin{array}{r}-0.30 \\
-0.25 \\
-0.58 \\
0.77\end{array}$ & $\begin{array}{r}0.30 \\
0.25 \\
0.58 \\
-0.77\end{array}$ & $\begin{array}{l}0.19 \\
0.45 \\
0.33 \\
0.05\end{array}$ \\
\hline & 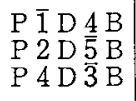 & $\begin{array}{r}-0.26 \\
-0.65 \\
0.95\end{array}$ & $\begin{array}{r}0.26 \\
0.65 \\
-0.95\end{array}$ & $\begin{array}{l}0.46 \\
0.34 \\
0.05\end{array}$ \\
\hline
\end{tabular}
the case of tensile stress). 
のおるて面に粒界近傍で大きなせん断応力， $-\tau_{y z}$ が生じ れば，粒界面に平行なすべり面をるつすべり系が活動する 可能性はもっていることになる。一方，らら面では，おも て面と異なる 2 次すべり系，P 2 D 6 A 就よ゙P 2 D 5 B (すべり面が粒界面に平行でない)が活動した。これらのす ベり系と隣接結晶の主すべり系間の応力伝達係数， $N_{i j}$ 值 は，0.45 および 0.47 とやや大きく，それらのすべり系の $+\tau_{y_{z}}$ に対する方位因子, $N_{i j}\left(+\tau_{y z}\right)$ 値は 0.63 および 0.58 , さらにシュミット因子す 0.32 款よび 0.38 と此較的大きか った.

また，生縮変形を各 Type の双結晶に与えると，粒界 近傍に発生するせん断応力， $\tau_{y_{z}}$ は，引張変形時の正負逆 となりかつすべり方向も逆になるため，方位因子， $N_{i j}$ $\left( \pm \tau_{y_{z}}\right)$ 值は各すべり系に対して, 引張変形時と同じ值を示 + .

このため双結晶が両振り曲げ疲労を受けることは，上記 すべり系の活動をさらに促進させることになる。

\section{V. 結言}

椟界が疲労き裂の発生に打よぼす影響を調べるたかに，

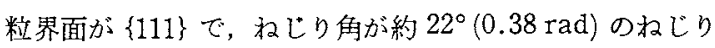
粒界をるつアルミニウム双結晶を作製し，繰返し速度 30.4 $\mathrm{Hz}$ および表面の最大ひずみ約 $0.2 \%$ の定ひずみ雨振り曲 げ疲労試験を行ない，次の結言を得た。

(1) 粒界に沿ら疲労き裂の発生和上び伝ばが観察され た。それらの疲労き裂の発生は，両成分結晶の塑性ひずみ (粒界面内のせん断ひずみ)の “incompatibility” のため, 粒界面に平行なすべり面をるつすべり系の活動が必要であ った。
(2) 塑性ひずみの“compatibility”においては，従来 の塑性ひずみの compatibility が隣接結晶の主すべり禾 の塑性ひずみとの差を考虑したのに加兄て，㱛接結晶間の 転位の集団的な相互作用(集団的な転位間の引力ゃ斥力)を 考虑する必要がある。

(3) 塑性ひすずの “incompatibility”をるつ双結晶で る, 粒界面にすべり面が平行でないすべり系の活動は，粒 界に沿ら疲学き裂の発生を起さなかった。

\section{文献}

（1）たとえば，P.T.E.Forsyth : Nature, 171 (1953)， 72 .

(2) G.C.Smith : Proc.Roy. Soc. A, $242(1957), 189$.

(3) D.S.Kemsley : JIM, 85(1956-57), 420.

(4) C.Laird and C.E.Feltner : Trans. Met. Soc. AIME, $239(1967), 1074$

(5) W.A.Wood, W.H.Reiman and K.R.Sargant: 'Trans. Met. Soc. AIME, $230(1964), 511$.

（6）美馬源次郎，猪子富久治，安宅 健，上崎孝一：軽 金属，28(1978)，130。

（7）猪子富久治，山地広，秋園幸一，美馬源次郎：日 本金属学会誌，39(1975)，467.

(8) F.Inoko, K.Akizono, H. Yamaji and G.Mima: Proc. 2nd Inter. Conf. on Mechanical Behavior of Materials, 16-20 August 1976.

(9) R. E. Petterson : Stress Concentration Design Factor, John Wiley, New York, (1974), 44.

(10) I.C.M.Li and C.D.Needham : J.Appl. Phys., $31(1960), 1318$.

(11) R.E.Hook and J.F.Hirth: Acta Met., 15 (1967), 535.

(12) T.D.Lee and H.Margolin : Met. Trans., $8 \mathbf{A}$ (1977), 145, 157 .

(13) J.C.Livingston and B.Chalmers : Acta Met., $5(1957), 322$.

（14）木村 節，猪子富久治，秋園幸一：日本金属学会講 演概要, (1978-4月), 243 . 